\title{
Swaziland and the International Monetary Fund ${ }^{1}$
}

\author{
By Joseph R. A. Ayee
}

\section{Introduction}

Africa's increasingly severe debt problems have become the central issue in the continent today. The Organization of African Unity (OAU) economic summit meeting in Addis Abeba in November 1987, like the Lagos summit of 1980, discussed the continent's debt, which now stands at over US\$ 300 billion. In the wake of balance of payment difficulties, most African countries have sought assistance from ma jor public international institutions, especially the International Monetary Fund (IMF) and the World Bank. According to Robert Wood, "perhaps the most visible and publicised political consequence of the debt crisis has been the increased role of the International Monetary Fund". 2

Contrary to popular belief, the Kingdom of Swaziland is not in severe debt crisis, unlike most African countries; and yet the country deals with the IMF and has adopted most of its conditionality. It should, however, be pointed out that the strength of the Swaziland economy is rather artificial because of its heavy reliance on the revenue of the Southern African Customs Union (SACU), which accounts for 60 per cent of total govemment revenue 3 and South Africa market and marketing facilities. ${ }^{4}$ The literature on SwazilandIMF relationship is inadequate and marked by substantial lacunae. This paper aims at making a modest contribution towards filling this gap within the limitations of available data.

1 Revised version of paper originally presented at the 11 th Southem African Universities Social Conference (SAUSSC) on the theme "International Financial Institutions and Socio-Economic Development in Southem Africa", held at the University of Swaziland, Kwaluseni, 27-29 June 1988.

2 Wood, RE., The Debt Crisis and North-South Relations, Third World Quarterly, vol. 6, No. 3, July 1983 , p. 705.

3 See Ayee, J.R.A., Swaziland and the Southem African Customs Union, Joumal of African Studies, vol. 15, Nos. $3 \&$ 4, Fall/Winter 1988, pp. $61-70$ for the costs and benefits of Swaziland's membership of SACU.

4 See Ayee, J.R.A., Political and Administrative Obstacles to Development Planning in Swaziland, Indian Joumal of Public Administration, vol. XXXIV, No. 1, January-March 1988, pp. 79-82. 


\section{The Evolution and Objectives of the IMF}

The IMF was established in 1944 as a result of the Bretton Woods monetary and financial conference of July that year. The Fund provides the machinery for consultation and collaboration between member countries on international monetary problems. The objectives of the Fund as contained in the Fund's Articles of Agreement include:

To facilitate the expansion and balanced growth of international trade, and to contribute thereby to the promotion and maintenance of high levels of employment and real income and to the development of the productive resources of all members as primary objectives of economic policy. 5 ... to shorten the duration and lessen the degree of disequilibrium in the international balances of payments of members. 6

\section{Operations and Lending Policies of the IMF}

A key feature of the IMF's financial support is that it is made available under conditions designed to promote effective adjustment and ensure that the use of resources by members is temporary and consistent with the Fund's objectives. 7 These condistions relate to the overall economic policies pursued by members: such policies should permit the return to balance of payments viability within a reasonable time frame, while at the same time encouraging economic growth and employment creation, promoting financial stability, and reducing trade and payments restrictions (or avoiding their intensification). 8

The resources of the Fund consist of the currencies of the Fund member countries, Special Drawing Rights (SDRs) and gold. These resources are received in the form of subscriptions (which are equal to quotas), borrowings, charges on the use of the Fund's resources, income from investments, and interest of the Fund's holdings of SDRs. Subscriptions are the main source of funds. 9 When a country joins the Fund, it is assigned a quota that fits into the structure of existing quotas considered in the light of the member's economic characteristics relative to those of other members of comparable size. The size of the

7 See Intemational Monetary Fund Annual Report 1988, IMF: Washington D.C. 1988, p. 47; Havnevick, K.T., The IMF and the World Bank in Africa: Conditionality Impact and Altematives, Scandinavian Institute of African Studies, Uppsala, 1987, pp. 7-16; The Brandt Report in the Handbook of World Development, Longman: Washington D.C., May 1989, pp. 6-22.

8 Ibid.

9 International Monetary Fund, International Financial Statistics, vol. XLI, IMF: Washington D.C., May 1989, p. 8. 
member's quota determines, among other things, the member's voting power, the size of its potential access to Fund resources, and its share in allocations of SDRs. 10

\section{Borrowings under the IMF}

Borrowings are regarded as a temporary source of funds. The Fund has the authority to borrow the currency of any member from any source with the consent of the issuer. The Fund's first borrowings were made under the General Arrangements to Borrow (GAB). The Arrangements were made in 1962 for an initial period of four years, but through successive extensions have been continuously in force since then.11 The Arrangements permit the Fund to borrow the currencies of ten industrial country members (those forming the group of Ten) to finance purchases by any of these ten countries. The Fund also has an agreement with Switzerland unter which Switzerland undertakes to consider making loans to the Fund to finance additional purchases by members that make purchases financed by GAB. The revised GAB, that became effective in December 1983, permit the Fund under certain circumstances to extend $\mathrm{GAB}$ resources to members that are not GAB participants, authorize participation of the Swiss National Bank, and permit certain borrowing arrangements between the Fund and nonparticipating members to be associated with GAB.12

The principal way in which the Fund makes its resources available to members is by selling them the currencies of other members or SDRs in exchange for their own currencies. Such transactions exchange the composition, but not the overall size, of the Fund's resources. A member to which the Fund sells currencies or SDRs is said to make "purchases" (also referred to as "drawings") from the Fund. The purpose of making the Fund's resources available to members is to meet balance of payments needs. 13 Before 1974, the Fund's resources were provided through the following: (i) the Credit Tranche Policy, which is often referred to as the Fund's "basic" financing policy. Credit under this policy is viewed as being available in tranches, each tranche being equivalent to 25 per cent of quota; (ii) the Compensatory Financing Facility, which was established in 1963, is to assist members, particularly primary producing countries, experiencing balance of payments difficulties attributable to shortfalls in eamings from merchandise exports and invisibles that are both temporary and due largely to factors beyond their control; (iii) the Buffer Stock Financing Facility, which was established in June 1969, is to provide assistance to members with a balance of payments need related to their participation in arrangements to finance approved

10 Ibid.

11 See Commonwealth Secretariat, Towards a New Bretton Woods: Challenges for the World Financial and Trading System, Commonwealth Secretariat: London, 1983, pp. 27-48.

$12 \mathrm{IMF}$, International Financial Statistics, p. 9.

13 The Brandt Report, in Handbook of World Development, pp. 14-25. 
international buffer stocks of primary products. Under the present guidelines, a member can have outstanding purchases under the facility of up to 45 per cent of quota. 14

\section{Changes in IMF Lending Policies}

Since 1974 far-reaching changes have taken place within the IMF, and also the fact that many other IMF lending facilities are for longer terms and subject to little conditionality. 15 In addition the IMF has introduced measures aimed at ensuring that conditionality and structural adjustment promote growth. In other words, the IMF has realized the crucial role of growth-oriented programms and their bearing on balance of payments resolution. Some of such programmes in operation are:

i. The Extended Fund Facility $(E F F)$, which was established in September 1974. It is aimed at making resources available for longer periods and in larger amounts, than under the credit tranche policies, to members that are experiencing balance of payments difficulties, owing to structural inbalances in production, trade, and prices, or that are unable to pursue active development policies because of their weak balance of payments positions. Ordinary resources are made available in instalments under extended arrangements to cover purchases 40 per cent of quota over a period of up to three years. 16

ii. The Supplementary Financing Facility was established in February 1979 to provide assistance to members facing payment difficulties that are large in relation to their economies and their Fund quotas. Resources under the Facility, which are borrowed and therefore are not part of the Fund's ordinary resources, are made available only in connection with an upper credit tranche stand-by arrangement and extended arrangement. 17

iii. The Policy on Enlarged Access to the Fund's Resources, which mainly continues the policies of the supplementary financing facility following the full commitment of the latter's resources became operational in May 1981. Resources are provided only under stand-by and extended arrangements. The amount of assistance available to a member under the policy is determined according to guidelines adopted by the Fund from time to time. Under the present guidelines, access by members under stand-by or extended arrangements is subject to annual limits of 90 or 110 per cent of quota, three-year limits of 270 or 330 per cent of quota, and cumulative limits of 400 or 440 per cent of quota (net of

14 Havnevick, The IMF and the World Bank in Africa, pp. 17-20.

15 See Nowzod, B., The IMF and Its Critics, Princeton University Press: Princeton, 1981, pp. 7-19.

16 Ibid. pp. 20-21.

17 Williamson, J., IMF Conditionality, Institute for Intemational Economics: Washington D.C., 1983, pp. 14-25. 
scheduled repurchases and excluding outstanding purchases under the compensatory financing facility and the buffer stock financing facility) depending on the seriousness of the member's balance of payments needs and the strength of its adjustment efforts. 18

iv. The Structural Adjustment Facility, established in March 1986 as a result of the Baker Plan of 1985, is a joint effort with the World Bank. The SAF provides additional balance of payments assistance in the form of loans on concessional terms to low-income developing countries that were eligible for International Development Agency (IDA) resources that face protracted balance of payments problems and are in need of such assistance. In December 1987, the Enhanced Structural Adjustment Facility (ESAF) was also established to provide the additional assistance in the form of loans on concessional terms to lowincome developing countries that were eligible for assistance from the SAF. The objectives, basic procedures, financial conditions, and financial terms applying to ESAF and SAF are identical. Resources are provided only under ESAF arrangements and are disbursed over a three-year period. 19

v. The Trust Fund, which was established in May 1976, provided balance of payments assistance on concessional terms to eligible members and also distributed funds directly to developing members. The resources of the Trust were derived from profits from the sale of about 25 million ounces of the Fund's gold holdings during 1976-80, from income on the investment of these profits, from contributions by members, and from low-interest borrowings. 20 The Trust Fund facility terminated on 30th April 1981, and after that date its activities have been confined to the completion of unfinished business and winding up of its affairs.

It is worth emphazising that some scholars 21 have sought to judge the IMF in accordance with the more stringent programmes only 22 , which are often applied when the condition of the country's economy has reached a terminal state, and ignoring other more liberal and ameliorating facilities available.

18 IMF, Intemational Financial Statistics, p. 9.

19 IMF, Annual Report 1988, p. 50.

20 Ibid. pp. 193-194.

21 See for instance Dell, S., Stabilization: The Political Economy of Overkill, World Development, vol. 10, No. 8, 1982, pp. 597-612; Makgetla, N.S., Theoretical and Practical Implications of IMF Conditionality in Zambia, Joumal of Modem African Studies, vol. 24, No. 3, 1986, pp. 395-422; Bura, A., IMF Financial Programmes and Conditionality, Journal of Development Economics, vol. 12, Nos. 1 \& 2, 1987, pp. 111-135.

22 The IMF interprets its responsibilities on banking principles, that is, the need to ensure that the loan principal and interest are repayed. This has led the Fund to insist on a mixture of policies which, it is hoped, would improve the balance of payment, making foreign exchange available for repayment of the loan and interest. The result if that the Fund has pressed for reductions in government spending and limits on the creation of credit, together with devaluation. 


\section{IMF - World Bank Co-operation}

The objectives of the Structural Adjustment Lending (SAL) are multiple: provision of finance, stabilization of demand and stimulation of supply. And of course, they frequently conflict. At the basic level, one variety of stabilization policy involves reduction of aggregate expenditure, which provides a disincentive to the expansion of supply. 23 Secondly, various policy measures for improving allocation (raising agricultural prices; reducing tariffs, offering subsidies for non-traditional exports) involve a reduction of public expenditure; and thus a counter-stabilization force at times of excess demand pressure on the economy. 24 Third, to the extent that SAL finance is conditional on policy changes of either kind, any failure to implement these changes "on time" will interrupt the provision of finance.25 A first required for the successful design of a structural adjustment package, therefore, is that these potential conflicts be acknowledged $e x$ ante, rather than be allowed to manifest themselves in the form of intemally inconsistent advice to a "bemused" recipient govemment. 26

This problem was of course recognized and tackled by the founding fathers of the Bretton Woods institutions, who created the IMF as a safeguard for the international financial system and the World Bank as a provider of long-term capital for development.27 However, as Feinberg has pointed out, a lot of work has been done to blur the edges of what was once a clear and sharp functional distinction. 28 With the advent of the Fund's Extended Fund Facility, the Bank's Structural Adjustment Lending and its derivatives, the Fund's concessional Structural Adjustment Facility and Extended Structural Adjustment Facility, both institutions came to be providing medium-term balance of payments credit designed to achieve adjustments on both the supply and the side.29

It is worth pointing out that both the IMF and the World Bank have recognized the attendant risk of treading on one another's toes: it is now common for Fund personnel to participate in Bank missions and vice versa, and both institutions have taken part in the preparation of medium-term policy frameworks (development plans in all but name) for

23 See Mosley, P. \& Toye, J., The Design of Structural Adjustment Programmes, Development Policy Review, vol. 16, 1988, p. 401.

24 Ibid.

25 See Mosley, P., Conditionality as Bargaining Process: Structural Adjustment Lending, Princeton Papers in International Finance No. 168, International Finance Section, Princeton, N.J., 1987, pp. 3-9.

26 Ibid. pp. 9-12.

27 Feinberg, $R$., The Changing Relationship Between the World Bank and the International Monetary Fund, Overseas Development Council: Washington D.C., 1986, pp. 6-8.

28 Ibid.

29 Mosley \& Toye, The Design of Structural Adjustment Programmes, p. 402. 
Malawi, Ghana and other countries. ${ }^{30}$ But conflict becomes inescapable when one instrument has a dual function, as is the case with tariffs on foreign trade (which, in Morocco in 1985, the Fund wanted raised for revenue reasons, and the Bank wanted reduced for allocative reasons), export subsidies and even primary product prices. For example, in Ghana in 1986 the Bank was pushing for a higher on-farm cocoa price to give the farmer an incentive and the Fund for a freeze on the price in order to maximize the yield from cocoa taxation. 31 When such conflicts arise, either the stabilization or the allocation objective is given priority by explicit agreement among the Fund, Bank and recipient government. 32

\section{IMF Stabilization / Structural Adjustment Policies}

In providing financial support for adjustment programmes, the Fund follows its guidelines on conditionality, which were reformulated in 1979. These guidelines emphasize the need to encourage members to adopt corrective measures at an early stage of their balance of payments difficulties. 33 They also provide that, while the normal period of a stand-by arrangement will be one or two years, in some cases they may extend up to three years; that a flexible approach to the reatment of external borrowing in adjustment programmes needs to be adopted34; and that due regard has to be given to the domestic social and political objectives, the economic priorities, and the circumstances of members, including their balance of payment problems. 35 Within this general framework, Zulu and Nsouli contend that:

considerable flexibility has been maintained in the application of conditionality. Particularly in countries with severe structural problems, greater emphasis has been placed on supply-oriented policies and increased financing over a sufficiently long period to allow fruition of the effects of the measures taken. 36

30 Feinberg, The Changing Relationship, pp. 9-10.

31 Mosley \& Toye, The Design of Structural Adjustment Programmes, p. 403.

32 World Bank, Structural Adjustment Lending: A First Review of Experience, Report No. 6409, World Bank, Operations Dept: Washington D.C., 1086, pp. 22-27.

33 Bacha, E.L., IMF Conditionality: Conceptual Problems and Policy Altematives, World Development, vol. 15, No. 12, 1987, pp. 1457-1458.

34 Zulu, J. \& Nsouli, S., Adjustment Programs in Africa: The Recent Experience, International Monetary Fund: Washington D.C., April 1985, pp. 5-6.

35 Zulu, J. \& Nsouli, S., Adjustment Programs in Africa: Experience with Fund-Supported Programs, 1980-81, Finance and Development, March 1984, p. 6.

36 See United Nations, Survey of Economic and Social Conditions in Africa, 1986-1987, United Nations: New York, 1988, pp. 15-16; Zulu \& Nsouli, Adjustment Programs in Africa, pp. 1-12; Bacha, IMF Conditionality: Conceptual Problems, pp. 1458-1464. 
Taking account of the diversity of situations among countries and of the different national strategies, it nevertheless can be said that IMF reforms and policy adjustments are made more or less along the following lines:

i. A new approach to the role of the state and the public sector in the economy. State intervention is seen in terms of providing incentives and supporting the production sectors rather than of direct control. The public sector is seen as requiring substantial reform, as it has more of ten been a drain on scarce national resources than augmented them;

ii. An emphasis on, and recognition of, the key role of incentives in agricultural production;

iii. A recognition of the need to introduce reforms in the economic system which will provide more flexibility and more freedom for economic agents.

While the Fund provided resources to support appropriate adjustment programmes, a primary concern of African countries that adopted such programmes was the achievement of a sustainable level of economic growth. However, the key to such sustainability was the establishment of domestic and external financial stability. If a country had high levels of domestic inflation, of ten reflecting excess demand pressures, savings and investment would be discouraged leading to a frop in economic growth. 37 Similarly, if a country faced protracted external imbalances, the shortage of foreign exchange could result in a curtailment of important imported inputs and capital goods. In addition, the distortions arising from an inappropriate exchange rate could undermine both the export-oriented and importcompleting industries. 38 Again, therefore, the sustainability of economic growth would be impaired. Accordingly, the IMF imposes its structural adjustment policy to achieve three basic and interdependent objectives; namely, to promote economic growth, to refice inflation and to improve the current balance of payments over the medium term. 39

The IMF adjustment programme has been criticised by scholars. Most countries still have difficulties with the IMF approach, particularly with its strong market orientation. 40 Another problem is the cost of structural adjustment in terms of living standards and of the trade-offs involved between different social groups, particularly between urban, public sector wage eamers and the rural population. 41 In 1987, there was a noticeable change of emphasis and increased flexibility on the part of the Fund, which has adopted a more growth-oriented approach, instead of proposing a somewhat rigid demand management and

37 Zulu \& Nsouli, Adjustment Programs in Africa, pp. 8-9.

38 Bacha, IMF Conditionality: Conceptual Problems, pp. 1457-1460.

39 Havnevick, The IMF and the World Bank in Africa, pp. 7-12.

40 UN, Survey of Economic \& Social Conditions in Africa, 1986-1987, p. 18.

41 Ibid. p. 19. 
debt-servicing package. The launching of the Structural Adjustment Facility was the fruit of that development. That serious obstacles remain is shown by the cases of Liberia, Sierra Leone, Somalia and Zambia, who have either withdrawn from arrangements or been barred by the IMF from receiving any stand-by credit. 42

Ghana has been singled out by the IMF as the country which has consistently followed IMF structural adjustment prescriptions, with accompanying improvement in the economy. In the words of the United Nations, adjustment efforts in Ghana "produced a turnaround in the economy, which is now growing at a commendable rate after years of stagnation and decline".43 The government introduced a three-year Structural Adjustment Programme (SAP) in 1987, of which a Public Investment Programme (PIP) was an integral part. The main elements of SAP relate to rade and payments, the key cocoa sector and the public sector. In 1987, one of the main measures was the unification of exchange rates - the fuel exchange rate system was terminated in February - accompanied by a devaluation of the cedit by 13.2 per cent. 44 Public spending was cut, the civil service ranks reduced and the number of employees in the cocoa board and other state enterprises also reduced. However, there were serious difficulties with rade unions and other urban interests who vehemently resisted the adjustment programmes. Furthermore, measures in 1988 and 1989 have led to thousand of redundancies because of rationalization, including privatization or liquidation of 30 state enterprises. 45

Another example of IMF structural adjustment policy could be found in Mozambique. In January 1987, the govemment initiated a recovery programm which included a substantial liberalization of the economy, until then a centrally planned one, and agreed on a SAF programme with the Fund. Under that programme there were two successive, substantial devaluations of the metical, increases in producer and consumer prices, more control of the public sector and more incentives for the agricultural sector. The positive results, according to a UN survey, was an increase in production and exports and the rescheduling of the external debt, which, in view of the state of war within the country and the economic decline, had become well-nigh unserviceable. 46 But there were also costs: the living standard of the urban population declined, while wages failed to keep up with prices.

42 Ibid. p. 19.

43 Ibid. p. 19.

44 Ayee, JR.A., The Political Implications of the Economic Recovery Programme of the Provisional National Defence Council of Ghana, Universitas, vol. 19, No. 3, 1989, forthcoming.

45 Ayee, JR.A., A Note on the Privatization of State Enterprises in Ghana, VRÜ, No. 2, 1989, pp. $121-130$.

46 UN, Survey of Economic \& Social Conditions in Africa, 1986-1987, p. 20. 
The foregoing shows that IMF structural adjustment programmes have their costs and benefits. The result is that performance under the programmes "is difficult to assess in so far as the assessment depends on the yardstick selected".47

\section{Review of the Swaziland Economy}

The economy of the Kingdom of Swaziland porrays an all-pervasive dependence on the Republic of South Africa. Apart from the banking sector which is dominated by the British Standard and Barclays banking groups, the growth in other sectors of the economy has been fuelled by south African, or South African based, investments. 48 In the manufacturing and commercial sectors, the most active investor has been the South African conglomerate, Kirsch Industries. This group dominates not only the maize milling and maize importation sectors but also holds the profitable Mercedes Benz and Nissan franchise in Swaziland. Kirsch also operates the country's largest trade wholesale and hardware and agricultural stores, and owns 50 per cent of the two largest shopping plazas together with a number of other manufacturing and commercial interests. 49 Other important South African conglomerates that maintain manufacturing subsidiaries in Swaziland include the Neopack subsidiary of the Barlow Rand Group, which dominates the packaging industry, and Swaziland Breweries, subsidiary of South African Breweries, which has a total monopoly of local malt beer production. 50

Apart from controlling most manufacturing industry in Swaziland, South African companies also dominate wholesale commerce. For instance, the country's largest supermarket is a branch of the OIC Bazaars subsidiary of South African Breweries, whilst numerous other smaller South African commercial undertakings operate in Swaziland. Moreover, more than 95 per cent of the imports into Swaziland come from South Africa, through a freight haulage system operated by South African railways. Viewed in this way:

with the exception of the few import substitution commodities produced in Swaziland (mainly by South African companies) Swaziland commerce consists largely of South African-owned companies selling South African-made products. 51

47 Zulu \& Nsouli, Adjustment Programs in Africa, p. 13.

48 Davies, R.H., O' Meara, D. \& Dlamini, S., The Kingdom of Swaziland: A Profile, Zed Books Ltd.: London, 1985, p. 11.

49 Ibid. p. 12

50 Daniel, J., The Political Economy of Colonial and Post-Colonial Swaziland, South Africa Labour Bulletin, vol. 7, Nos. 6-7, June 1982, pp. 100-105.

51 Davies et al., The Kingdom of Swaziland, p. 12. 
The tourist industry is also dominated by South African based companies. Most important of these is the Sun International group which owns four hotels in Swaziland, including the lucrative Royal Swazi Sun and Nhlangano Sun casinos. Started in 1969, these operations have provided white South Africans with what Davies et al. refer to as a "range of gambling and sexual services banned in South Africa itself, and have inspired their reproduction in other neighbouring states and the independent bantustans".52

The "octopus-like grip on the Swazi economy"53 by South African capital is more or less institutionalized through the Southern African Custom Union (SACU), which was established in 1910. SACU was established to provide a free trade area between the four member countries, the BLS states - Botswana, Lesotho and Swaziland - South Africa itself. Custom union receipts have accounted for more than 60 per cent of Swaziland's total revenue and grants. The actual percentages have varied from a low 46.7 per cent in 1981/82 to 64.6 per cent in 1982/83 and 1986/88. Distribution of revenue under SACU has not been given without political strings attached. For instance, it has become a means for rewarding of or punishing the BLS countries for their behaviour in the region. This, in fact:

became clear in the mode of distributing SACU revenue for the year 1981-1982. South Africa invited the BLS countries to submit their revenue claims according to the 1976 formula. Swaziland claimed R 117 million (compared with R 52.7 million for the previous year). South African of ficials replied that this was an overestimation and that the figure should be around R 64 million. However, this position was reversed by the South African cabinet which "noted the error, but accepted the former figure". 54

As a landlocked country, Swaziland is virtually totally dependent on South Africa for its external trade.55 The Maputo rail and road link in Mozambique is its only alternative access to the outside world. The figure on exports, according to Davies et al., is lower, as much of Swaziland's major export sugar, together with some coal, is exported through Maputo. 56 No attempt has been made by the Swaziland authorities to develop this outlet and so reduce reliance on the South African railways.

Specifically viewed, economic statistics appear to indicate that the Swazi economy is relatively diversified. In 1987/88 the manufacturing sector contributed 27 per cent of the country's GDP of R 518 million. Agriculture and forestry contributed 25 per cent and the

52 Ibid. p. 12.

53 Ayee, Swaziland and the Southem African Customs Union, p. 65.

54 Davies et al., The Kingdom of Swaziland, p. 14.

55 Crush, J., The Parameters of Dependence in Southem Africa: A Case Study of Swaziland, Joumal of Southem African Affairs, vol. VI, No. 1, January 1979, p. 56.

56 Davies et al., The Kingdom of Swaziland, p. 13. 
public sector 15 per cent. 57 The manufacturing and the distribution, hotel and restaurant sectors were the two fastest growing sectors to the Swaziland GDP in 1987/88 fiscal year. 58

The years 1980 - 1985, witnessed a downward trend in Swaziland's economy. This severe recession was aggravated by the impact of a drought and the cyclone Demoina, which devastated the country in January 1984. In his February 1984 budget, the Minister of Finance acknowledged that "in economic terms, Swaziland is at present undergoing one of the most difficult periods of its history".59 No real growth of GDP had been recorded in the previous two years compared with growth rates of 10.9 per cent and 7.5 per cent in 1978 and 1982 respectively. There had been a number of bankruptcies, the most important being that of the giant French-owned fertilizer company, Swaziland Chemical Industries (SCI). This was declared insolvent in March 1984 with debt of R 29 million.60 The extend of the recession was also reflected in the fact that for several years the country had experienced a rising deficit on its balance of payments account. After allowing for the inflow of long and short-term capital and foreign grants, this deficit reached R 63 million in 1983/84, compared with R 15.7 million in 1981/82.61

The major reason for the growing fiscal crisis of the Swaziland state during the 1980 - 1985 period was the dramatic decline in revenue. In particular, government receipts from the two principal exports, sugar and wood pulp declined, because of low international prices. Of course, this does not reflect a dramatic decline: sugar has risen continuously since 1983, and the 1985 decline of wood pulp relative to 1984 was not severe either. The following table portrays this vividly:

Table 1: Exports of the Kingdom of Swaziland Millions of Emalengeni

\begin{tabular}{lrrrrrr} 
Commodity & 1982 & 1983 & 1984 & 1985 & 1986 & 1987 \\
\cline { 2 - 7 } Sugar & 351.80 & 338.50 & 340.50 & 385.20 & 606.05 & 632.00 \\
Wood Pulp & 123.01 & 121.87 & 140.57 & 139.55 & 245.30 & 223.63
\end{tabular}

Source: IMF International Financial Statistics, Vol. XLII, No. 5, May 1989, New York; IMF, pp. 496-497.

57 Kingdom of Swaziland, Economic Review and Outlook, Swaziland Publishing \& Printing Co.: Mbabane, 1988, pp. 8-15.

58 lbid. pp. 16-18.

59 Kingdom of Swaziland, Budget Speech Presented to Parliament by Minister of Finance, 1984, p. 2.

60 Daniel, The Political Economy of Colonial and Post-Colonial Swaziland, pp. 108-110.

61 Davies et al., The Kingdom of Swaziland, p. 30. 
There was, however, favourable economic result in 1986 partly as a result of increase in export eamings from sugar and wood pulp, while imports reduced by a third, and partly because of the revision of the SACU formula. 62

The other point one needs to consider while reviewing Swaziland's economy is the country's role as a sanctions-busting centre. As a result of the relocation of firms from South Africa to Swaziland since 1985, the manufacturing sector has benefitted at the expense of the other sectors. The following table illustrates this:

Table 2: Breakdown of Swaziland GDP 1985-88

\begin{tabular}{lccc} 
Year & $1985 / 86$ & $1986 / 87$ & $1987 / 88$ \\
\hline Sector & $\%$ & $\%$ & $\%$ \\
\hline Agriculture/Forestry & 10 & 21 & 22 \\
Manufacturing & 30 & 34 & 38 \\
Hotel \& Restaurants & 22 & 21 & 20 \\
Others & 28 & 23 & 20 \\
Total & 100 & 100 & 100
\end{tabular}

Source: Swaziland Annual Statistical Bulletin (Mbabane: Central Statistics Office, 1985-88); Economic Review (Mbabane: Prime Minister's Office, 1985-88).

The relocation of forms from South Africa to Swaziland include Swazi Carpets that relocated its operations from the Transkei Bantustan and the Kirsch Industries which established a textile factory in Swaziland. The relocation exercise was a roundabout turn by the Republic of South Africa, which during the early 1980s embarked upon an exceedingly attractive incentives policy to industrialists prepared to invest in South Africa's bantustans and adjacent areas under South Africa's "deconcentration" policy.

\section{Swaziland's External Debt}

During a discussion on the 1988 budget, the Minister of Finance revealed to parliament that Swaziland's external debt stood at US\$232 million. Of this sum, US\$120 million was made by govemment while the remaining was made by parastatal organizations. 63

62 See Ayee, Swaziland and the Southem African Customs Union, for a summary of the revisions of the SACU fornula.

63 The Times of Swaziland, Mbabane, February 1988, p. 28. 
Taking into account the performance of the economy, especially from 1986 onwards, with regards to balance-of-payments, Gross Domestic Product and external debt, it is tempting to say that the Swaziland economy has not done badly.64 For instance, the external debt of Swaziland (US\$232 million) in 1986 was $53.44 \%$ of GDP, while debt service as a percentage of GDP for the same year was $5.72 \% .65$ In his 1988 budget speech, the Minister of Finance was quite happy about the performance of the economy. He remarked:

Much improved performance in 1988 and 1987 mean that government's financial position is currently healthy, and by building on recent achievements, and maintaining our prudent fiscal and monetary stance, we can meet the possible difficult times ahead with some confidence. 66

He, however, cautions that although the economy is healthy, it needs a carefully controlled diet to keep growing:

The future remains uncertain, and we must continue to ensure that funds are used efficiently and that wasteful und unnecessary expenditure is reduced to a minimum ... if we consolidate upon the progress made since the dark days of 1985 , we can halt the dilution of the recurrent surplus while still continuing to provide services needed by our people. 67

Swaziland is therefore credit-worthy, since she satisfied certain indicators of creditworthiness, such as ratio of debt service to exports, interest to govemment revenue and total debt to GDP. 68

\section{Szwaziland - IMF Relationship}

As we indicated earlier on, although Swaziland is not in severe financial crisis, she has established ties, with the IMF. This relationship mainly takes the form of IMF team visiting Swaziland annually and preparing studies designed to assist the country in formulating economic policies. Swaziland's use of IMF's facilities is reflected in the following table:

64 See Tables 5, 6, 7 \& 8 .

65 Compare these ratios with the other Southem African States on Table 6. For a comparative analysis of the balance of payments and reserves, GDP and GDP per capita of the Southem Africa Countries see Tables $5,6,7 \& 8$.

66 The Times of Swaziland, Mbabane, February 1988, p. 1.

67 Ibid.

68 For a comparative analysis of these ratios of Swaziland with those of its Southem African neighbours, see Tables $5,6,7 \& 8$. 
Table 3: Swaziland's Use of IMF Facilities (Million of SDRs)

\begin{tabular}{rrrrrrr}
1982 & 1983 & 1984 & 1985 & 1986 & 1987 & 1988 \\
\hline 18.00 & 24.70 & 24.70 & 24.70 & 24.70 & 24.70 & 24.70 \\
4.98 & 1.47 & 2.29 & 2.26 & 2.24 & 2.79 & 1.23 \\
.01 & 1.70 & 1.73 & 1.76 & .03 & .03 & .01 \\
$\cdots-$ & 9.98 & 9.98 & 9.08 & 5.62 & 2.25 & $-\cdots$ \\
--- & .98 & .98 & --- & \multicolumn{1}{c}{--} & --- & --- \\
4.50 & 4.50 & 4.50 & 3.85 & 2.96 & 2.06 & 1.17
\end{tabular}

Quota

SDRs

Reserved Position in Fund

Comp. Financing Facility

Buffer Stock Facility

Trust Fund Loan Outst.

Source: IMF, International Statistics, Vol. XLII, No. 5, 1989, pp. 496-497.

The table shows that Swaziland utilised only a few of the facilities available under the IMF growth oriented programmes: namely, the Special Drawing, compensatory financing buffer stock and Trust fund facilities.

The IMF studies have sometimes gone a long way to shape economic policies in Swaziland. The IMF study reports contain mainly the much vexed structural adjustment policies. Swaziland became a member of the IMF after independence in 1968. The result of IMF Swaziland relationship is reflected in the following economic policies adopted by the government:

Foreign Investment: One of the basic components of IMF stabilization policies is greater hospitality to foreign investment and a general opening up of the economy to international commerce. The Government of Swaziland operates an open door policy designed to attract foreign investment. The National Industrial Development Corporation of Swaziland (NIDCS) is the parastatal charged with the function of soliciting capital and, in its operations, it offers generous incentives common to the Southem African peripheral and homeland states. In its promotional literature NIDCS makes a virtue of Swaziland's cheap labour structure and emasculated labour movement:

wages in Swaziland are low even when compared with those in other African countries ... Swaziland has one effective trade union ... strikes are rare.69

It also stresses the state's desire to work in partnership with outside capital and its normal policy is that investors should have at least 51 per cent share capital. In fact, that percentage is unually a good deal higher as NIDCS will not normally take more than 40 per cent of the 
equity and "neither does it desire to manage any enterprise as it considers this is the prerogative of the promoting technical partner".70

Generous tax incentives operate in the Kingdom of Swaziland with a view to attract foreign investors. The following table shows in comparative perspective tax incentives within the BLS countries:

\section{Table 4}

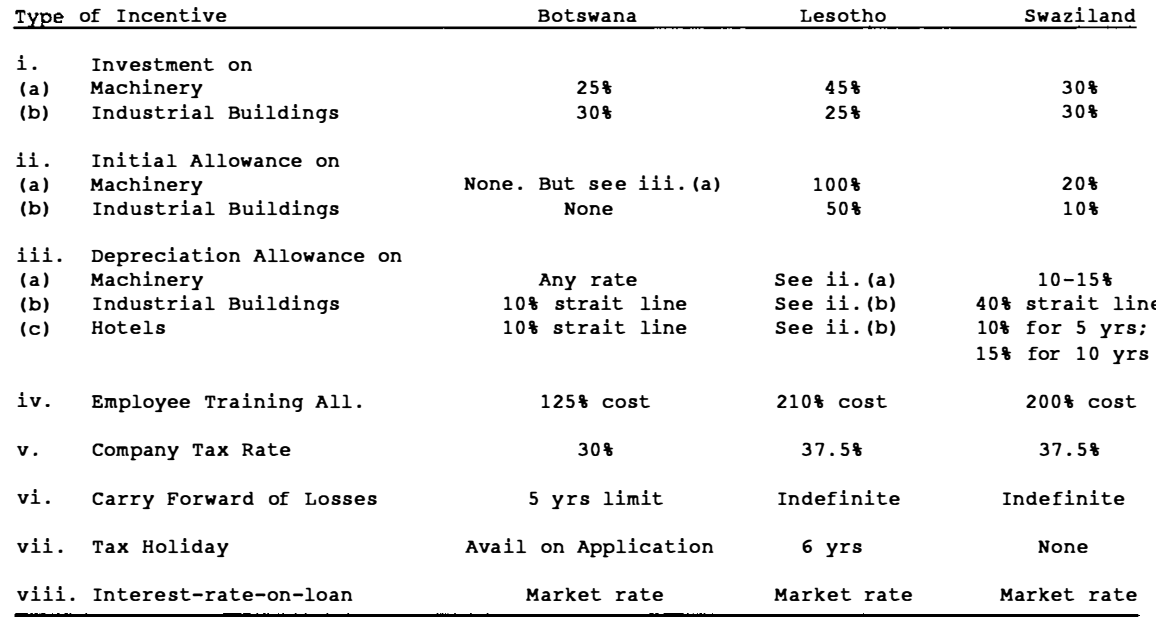

Source: NIDCS Guide to Investors, 1987; Botswana and Lesotho Statistics are from their Economic Surveys, 1986/87

Two observations could be made on the table. First, Lesotho offers the most generous tax incentives among the BLS countries. The tax incentives offered by Botswana and Swaziland are more or less comparable on an overall basis. Hence, from an overall viewpoint, the tax incentives offered by Swaziland are certainly not the most attractive in the region. The second observation is that Swaziland's tax incentives are tied more to capital-usage than to labour usage. As such, they do not attempt to positively induce labour-intensive, as opposed to capital-intensive, activities.

Despite the rather excellent investment facilities in Swaziland there has been moves in 1988 to protect the Swaziland element of any partnership. The stance of the present Minis-

70 The Swazi Observer, Mbabane, September 1981, p. 3. 
ter of Commerce and Industry is definitely in a different direction. Another hindrance to the good investment climate in Swaziland is the 1988 Royal Land Decree which was seen by all investors as a move towards discouraging investment and against free market forces. Despite strong representations against the act, and King Mswati III's intimination to review the move, nothing has been done to date.

The NIDCS guidelines to investors also provide the following:

(a) avoidance of nationalization;

(b) the free transfer of profits and dividends derived from local trading, subject only to a $15 \%$ non-resident shareholder's tax;

(c) interest, royalties and director's fees are easily transferred out of the country. Apart from these incentives strikes are frowned upon in the country. This was re-echoed by King Mswati while opening an Interboard factory at Nhlangano in September 1987:

The existence of cordial relations is an important factor in the success of Swaziland's effort to attract foreign capital investment because no investor will dream of putting his money in a country that is thom apart by strikes and industrial turmoil. All branches of my government shall do everything in their power to maintain, at all times and under all circumstances, the good recort of cordial industrial relations in our country. 71

Despite the King's admonition there had been a resurgence of labour militancy since 1987. A number of strikes had taken place at the Malkerns Fruit Cannery, the Mhlume Sugar Company, Havelock Asbestos Mine and the Mpaka Coal Mine.

The reliance on foreign investment coupled with Swaziland being a free and stable field for foreign capital investment has become a national policy, if not an ideology. Speaking in 1987 the King assured

all present and prospective investors that Swaziland will continue its policy of a free market economy in which private ownership and the right to make profit on your investment are completely guaranteed. We believe that private investment must play an important role in our national development process. We are convinced that Swaziland needs a steady flow of foreign capital into the country to help establish industrial projects ... in order to expand our economy. 72

71 The Swazi Observer, Mbabane, September 1981, p. 1.

72 Ibid. p. 4. 


\section{Control of Government Deficit / Expenditure Control}

As a result of IMF directives and efforts by govemment to contain its spending growth the knife is vigorously applied to all expenditure proposals in order to prune them. Control of government deficit is in the form of curbs on spending, especially in areas of social services along with increases in charges of parastatals. Capital expenditure on social services has consistently been inadequate. For instance, in 1987/88 fiscal year health and housing received an average share of $6.8 \%$ and $1.3 \%$ respectively. 73 As a result health facilities and personnel in Swaziland are grossly inadequate; while it is only the rich in society who can get access to good medical treatment in the Republic of South Africa.

A number of measures had been taken at least to reduce government deficit, which forms $15 \%$ of total expenditure. 74 These include the retrenchment of public sector personnel, a freeze of employment and the restructuring of government departments. Since 1984 to 1988 over 15,850 people or $10.5 \%$ of the workforce in the public sector were laid off. 75 In the 1984 budget speech, the Minister of Finance argued that "it was hard to justify" the existing level of expenditure on personnel in state departments, and referred approvingly to a 1984 IMF study which concluded that the level of employment in the state sector in Swaziland was "relatively large ... compared to similar developing countries".76 Ministries had been asked to shed much of the surplus government work force. During the 1988 budgetary estimates discussion of the Ministry of Labour and Public Service, a Member of Parliament remarked:

There is one civil servant to every five Swazis and it is time to apply the brakes before everyone becomes a civil servant. Instead of a job being done by two people, it is now being done by five. For every civil servant, there are 2.5 employees in the private sector. 77

Although there is little state intervention in the economy in Swaziland, the government has gone ahead with an IMF prescription of privatization of state enterprises in the country. In the light of financial losses experienced by parastatals like the Royal Swazi Airways, Railways, Water and Sewerage, Electricity Board and Television and Broadcasting, despite substantial increases in their charges of services provided, the government has earmarked

73 See Ministry of Finance, Swaziland, Functional Classification of Govemment Capital Expenditure, 1982/83-1987.

74 See Budget Speech by the Minister of Finance, 1988, pp. 5-8.

75 See Ayee, JRA., Localization Policies and Programmes in the Kingdom of Swaziland: Some Lessons of Experience for the Southem African Region, Phillipine Journal of Public Administration, vol. 5, No. 4, 1989, forthcoming.

76 Davies et al., The Kingdom of Swaziland, p. 31.

77 The Times of Swaziland, Mbabane, March 1988, pp. 1-2. 
some of them for privatization. When he was asked whether it would be economically and politically prudent to privatize parastatals, the Minister of Finance replied:

In an economy very much oriented towards the free market, privatization is an option which must always be bome in mind ... Debt is justified by the retum eamed on the project it finances. 78

\section{Liberalization of Exchange Rate and Import Controls}

Swaziland operates a flexible exchange rate and import control policy. The balance of payments position of South Africa is the key variable which determines foreign exchange availability, and therefore, credit-worthiness in the whole Rand Monetary Area (RMA). Presently, exchange rate and interest rate policies followed by South Africa ensure, by and large, foreign exchange availability in the RMA. Consequently anyone in Swaziland who has the necessary local currency (Rand or Lilangeni which are interchangeable) can purchase the foreign currency needed to service external debt. Swaziland holds $25 \%$ of her reserves outside the South African Reserve Bank which ameliorates her dependence in South Africa. Nevertheless, if there is a major balance of payments crisis in South Africa, the public or private sector will be unable to obtain the needed foreign exchange.79 Again, Swaziland has a liberal import controls policy. As we pointed out earlier on, large-scale commerce is dominated by South Africa. This trend has led observers to describe Swaziland as the "dumping ground" for South Africa goods.

\section{Devaluation of the Official Exchange Rate}

The IMF is unable to recommend devaluation of the official exchange rate of the Swazi currency. This is because in the case of Swaziland the foreign exchange rate is set a parity to the Rand in keeping with the Rand Monetary Agreement. Consequently, there is no scope for an independent foreign exchange rate policy. Swaziland is thus saved from the agonizing massive devaluation policy of the IMF. In general, devaluation is recommended by the IMF to increase exports and to encourage domestic production of goods to replace imports. Imports are made more expensive and this encourages switching to domestically produced alternatives. An important component of IMF thinking has been that devaluation alone would not improve the balance of payments; it must be accompanied by a reduction in money supply, which in Africa invariably requires a reduction in the public sector budget

78 The Swazi Observer, Mbabane, June 1987, pp. 7-9.

79 World Bank, Economic Memorandum on Swaziland, Country Programmes Department 1, Eastem and Southem Af rican Regional Office, 1985. 
deficit. Devaluation raises the cost of imported foods and industrial inputs, which help to depress living standards. As noted earlier on, Swaziland is not in balance of payment difficulties to necessitate the devaluation prescription of the Fund.

\section{Conclusion}

As readers will recall, the aim of this paper is to make a modest contribution towards the filling of gaps between Swaziland and IMF relationships. In the process, we have found that although Swaziland is not in serious financial crisis, she has adopted many of the policies that would be demanded by the IMF, with the exception of devaluation. We have also demonstrated that the IMF has growth-oriented programmes that seek to ameliorate its stringent programmes. Swaziland, however, utilized only a few of these growth-oriented facilities.

The lesson that this paper seeks to convey is that the IMF is a "hydra-headed monster" and like the legendary "Colossus bestriding" the world economic system, which a country cannot avoid in the global capitalist economic system, her financial strength notwithstanding. It should be pointed out, however, that although Swaziland adopted many of the IMF's traditional prescriptions, their effect on the Swazi economy has been positive because of the special position Swaziland enjoys under the Southern African Customs Union (SACU) and the nature of the dependence of its economy on that of South Africa. Surely, the nature of this relationship and the consequences of the IMF "medicine" is quite different from the Zambian, Sudanese, Nigerian, Tunisian, Tanzanian, and Zairean cases where the programmes caused food riots, as well as necessitating either their abandonment or drastic modification. 


\begin{tabular}{|c|c|c|c|c|c|}
\hline \multirow[b]{3}{*}{ Country } & \multicolumn{4}{|c|}{$\begin{array}{l}\text { External Debt and } \\
\text { Debt Service Ratio }\end{array}$} & \\
\hline & \multicolumn{2}{|c|}{$\begin{array}{l}\text { Millions of } \\
\text { Dollars }\end{array}$} & \multicolumn{2}{|c|}{$\begin{array}{l}\text { As Percentage } \\
\text { of GDP }\end{array}$} & G \\
\hline & 1982 & 1986 & 1982 & 1986 & 1982 \\
\hline Angola & 1098 & -- & 26.96 & -- & 6.0 \\
\hline Botswana & 1098 & 358 & 152.71 & 47.35 & 35.2 \\
\hline Lesotho & 121 & 186 & 34.02 & 48.72 & 2.6 \\
\hline Malawi & 870 & 1114 & 72.79 & 93.01 & 5.2 \\
\hline Swaziland & 184 & 232 & 34.06 & 53.44 & 3.3 \\
\hline Zambia & 3644 & 5300 & 94.30 & 192.33 & 4.5 \\
\hline Zimbabwe & 1844 & 2480 & 27.16 & 47.16 & 2.0 \\
\hline
\end{tabular}




\section{Table 6}

\begin{tabular}{|c|c|c|c|c|c|c|}
\hline \multirow[b]{3}{*}{ Country } & \multicolumn{4}{|c|}{ Balance } & $\& \mathrm{Re}$ & erves \\
\hline & \multicolumn{2}{|c|}{$\begin{array}{l}\text { Factor } \\
\text { Service } \\
\text { Net }\end{array}$} & \multicolumn{2}{|c|}{$\begin{array}{c}\text { Unrequited } \\
\text { Transfer } \\
\text { (Net) }\end{array}$} & \multicolumn{2}{|c|}{$\begin{array}{l}\text { Current } \\
\text { Balance }\end{array}$} \\
\hline & 1982 & 1985 & 1982 & 1985 & 1982 & 1985 \\
\hline Angola & -- & -- & -- & -- & -- & \\
\hline Botswana & -159 & 56 & 96 & 84 & 59 & 137 \\
\hline Lesotho & -84 & -47 & -37 & 60 & -121 & 13 \\
\hline Malawi & -59 & -- & 27 & -- & -72 & \\
\hline Swazilland & -1 & -91 & 82 & 47 & 80 & -44 \\
\hline Zambia & -575 & -100 & -40 & 1 & -615 & -98 \\
\hline Zimbabwe & -624 & -- & -82 & -- & -706 & 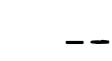 \\
\hline
\end{tabular}

Source: United Nations, Survey of Economic and Social Conditions in Africa, New York: L 


\begin{tabular}{|l|r|r|r|r|r|r}
\hline \multirow{2}{*}{ Country } & \multicolumn{5}{|c|}{ GDP and GDP Per Capita } & (At Cu \\
\cline { 2 - 7 } & \multicolumn{5}{|c|}{ Total GDP } & \\
\cline { 2 - 7 } & 1982 & 1983 & 1984 & 1985 & 1986 & 1982 \\
\hline Angola & 3324 & 3494 & 3924 & 4391 & 4453 & 418 \\
Botswana & 609 & 802 & 763 & 549 & 658 & 621 \\
Lesotho & 297 & 303 & 276 & 227 & 266 & 212 \\
Malawi & 1084 & 1102 & 1062 & 980 & 1072 & 169 \\
Swaziland & 1426 & 1262 & 1927 & 1318 & 1852 & 261 \\
Zambia & 3456 & 2795 & 2345 & 2627 & 2293 & 582 \\
Zimbabwe & 6077 & 5009 & 4528 & 4087 & 4670 & 813 \\
\hline
\end{tabular}


Table 8

\begin{tabular}{|l|r|r|r|r|r|r}
\hline & \multicolumn{7}{|c}{ Annual $\begin{array}{r}\text { Growth Rates of GDP a } \\
\text { At Constant 1980 Fac }\end{array}$} \\
\cline { 2 - 7 } & \multicolumn{6}{|c|}{ GDP Total } \\
\cline { 2 - 7 } Country & -1981 & 1982 & 1983 & 1984 & 1985 & 1981 \\
\hline Angola & 4.60 & 0.08 & 4.98 & 4.59 & 3.39 & 1.67 \\
Botswana & -2.59 & 25.04 & 20.29 & 5.68 & 5.12 & -5.78 \\
Lesotho & -2.07 & -2.04 & 3.70 & 2.40 & 1.00 & -4.02 \\
Malawi & 3.00 & 3.60 & 3.80 & 2.90 & 4.46 & 0.00 \\
Swaziland & 2.58 & -1.81 & 2.50 & 3.00 & 2.29 & -0.26 \\
Zambia & -3.75 & -1.93 & -0.36 & 1.49 & 0.53 & -6.70 \\
Zimbabwe & 0.63 & 1.71 & 0.54 & 5.56 & 1.74 & -3.28 \\
\hline
\end{tabular}

Source: United Nations, Survey of Economic and Social Conditions in Africa, New York: I 


\title{
Swaziland and the International Monetary Fund
}

\author{
By Joseph R. A. Ayee
}

One of the most notable repercussions of the debt crisis in Africa has been the increasing influence it has given the International Monetary Fund (IMF) over economic policy formulation by governments throughout the continent. Most African countries have been obliged to request IMF assistance at one time or another and have consequently found themselves bound by the Fund's conditionality.

This paper explores Swaziland - IMF relations. It argues that although Swaziland is not facing serious economic crisis, unlike most African countries, she has adopted and consistently followed most of IMF conditionality, which includes a programme of public spending cuts, liberalization of foreign exchange and import controls, hospitable attitude to foreign investment and general opening up of the economy to international commerce.

The one lesson to be leamt from Swaziland - IMF relationship is that the Fund is like a "Colussus bestriding" the world economic system, which a country cannot avoid in the global capitalist economic system, notwithstanding her financial strength. 